\title{
Fiction with an Iowa City Setting: An Annotated Checklist
}

Iowa City and The University of Iowa have been home for many writers. The Iowa Writers' Workshop, which will celebrate its fiftieth reunion in May, and the International Writing Program are at present the best-known cultivators of creative writing on the University campus. But student publications, especially the lowa Literary Magazine, 1924-30, and the encouragement of writers by the Department of English are traditions that began much earlier.

Students, professors, and visitors have sometimes turned to the local scene for their subjects. Many works, therefore, fall into the category of academic novels, primarily about students or professors. Published studies and bibliographies of academic novels list several UI novels and provide a context for them. ${ }^{1}$ The University of Iowa Hospitals and Clinics, which form a large part of the Iowa City community, have also provided subjects for novelists. Athletics is becoming a new topic for local literary exploration.

Many of these novels bring out-of-state visitors to the University or the city, giving their writers an opportunity to comment on local characteristics or problems. In many of the novels of the sixties and later decades, several patterns can be discerned. Counterculture sexual behavior, drugs, student demonstrations, avaricious landlords, farmhouses, and Volkswagens can be anticipated as almost a set formula. The downtown Iowa City urban renewal project continues to be severely criticized, both for the closing of Donnelly's Bar, which is sometimes disguised under other names, and for the alleged poor architectural quality of the new buildings. Several writers who refer to Meredith Willson, author of The

1 John E. Kramer, Jr., The American College Novel: An Annotated Bibliography (New York: Garland, 1981); John E. Kramer, Jr., and John E. Kramer III, College Mystery Novels: An Annotated Bibliography, Including a Guide to Professional Series-Character Sleuths (New York: Garland, 1983); John O. Lyons, The College Novel in America (Carbondale: Southern Illinois University Press, 1962); and Lyons, "The College Novel in America: 1962-1974," Critique: Studies in Modern Fiction 16, no. 2 (1974):121-28. 
Music Man, mistakenly assume that his "River City" refers to Iowa City, not Mason City, and all of them misspell his name as "Wilson." Old Capitol, the University's central building and symbol, unsurprisingly, is almost always in the background. The University president, for whatever reasons, is rarely mentioned in Iowa City novels, unlike novels set at other academic institutions. Local places and people may be portrayed with their real names but more often they are thinly or heavily disguised. Writers sometimes make obvious factual errors, though these gaffes do not usually detract from their stories.

The current reputations of the following authors seem to stand in direct proportion to the quality of their writings. Vance Bourjaily's Now Playing at Canterbury is probably the best novel for description of Iowa City and the University and for portraying the state of mind of its characters. Philip Roth's Letting Go and John Irving's The World According to Garp are important novels with comparatively little on Iowa City. The recent athletic novels by David Shields and W. P. Kinsella are more entertaining to read than most in the list. Elizabeth Hardwick has the best lines about reactions to Iowa City; her comments should be compared to nonfiction articles by John Cheever and others. ${ }^{2}$

The novels, short stories, and creative writing dissertations listed below are set, at least in part, in Iowa City. Cedar Rapids and Mount Vernon novels with only incidental mention of Iowa City are excluded. The annotations concentrate on the Iowa City settings rather than on character development or literary value. I am grateful to the many people who gave me leads to the following works; their interest and assistance are appreciated. Several printed sources have also been useful in identifying Iowa City fiction. ${ }^{3}$ The compiler alone is responsible for omissions and errors of interpretation. Additions will be welcomed.

\footnotetext{
2 John Cheever, "An Afternoon Walk in Iowa City, Iowa," Travel \& Leisure 4, no. 9 (September 1974):32-33, 50; Laurence Lafore, "In the Sticks," Harper's Magazine 243, no. 1457 (October 1971):108-9, 112-15; and Philip Roth, "Iowa," Esquire 58, no. 6 (December 1962):132, 240, 242-44, 247-48, 250.

${ }^{3}$ Among them, "Summer Reading for Iowa Citians," Prairie Grass (Iowa City) 3, no. 2 (March 1978): [8].
} 
1.

Barza, Steven Lee. SCISSORS, PAPER, ROCK: A NOVEL. Ph.D. dissertation, The University of Iowa, 1975. 3481.

Here is a novel apparently set in but not really about Iowa City. One major character teaches at Casehill College and rents a farmhouse in Amishland, on the highway beyond the Joetown flat. Except for the Inner City Revival Program and its streets blocked for repaving, the town, Stockton, in central Illinois, does not physically resemble either Iowa City or the genuine Stockton in Illinois near Galena.

2.

Berryhill, Clint. TAKE A CHANCE ON ME. Fayette, Iowa: Iowa Authors Publishing Company, 1983. 268 pp.

An Iowa country doctor set his first novel at the University in Iowa City. A rape victim and her rescuer, both freshman athletes from farm families, meet through violence and find love. The author's philosophizing overwhelms his characters' speech. Physicians at the University Hospitals are praised highly; lawyers fare less well.

3.

Blaise, Clark. LUSTS. Garden City, New York: Doubleday, 1983. $253 \mathrm{pp}$.

Philip Roth, then only 28, leads a story discussion in the Iowa Writers' Workshop in this novel by Clark Blaise, who both studied and taught in the workshop. The hero spends two years in Iowa City in the early sixties, a crucial interlude in a life stretching from Pittsburgh through Kentucky and New York to India. His life is changed forever in Iowa when a splinter on a library table severs an artery. Shortly before that painful event, he headed "uphill to Kenney's Bar, where the writers hung out, and over pitchers of beer and schooners of popcorn," they "would batter each other silly with opinions, with trivia, with judgments. We found all the soft spots in allegedly great stories."

4.

Bourjaily, Vance. NOW PLAYING AT CANTERBURY. New York: Dial Press, 1976. 518 pp.

Bourjaily, formerly of the Iowa Writers' Workshop, uses State University, State City, along the State River, as the setting for a novel centered around the opening of a new auditorium in 1972. (The new Hancher Auditorium on The University of Iowa campus was dedicated in 1972.) Several professors (one of whom, like the author, owns a farm near the town) and students produce a new opera and live the antiwar protests of the sixties and early seventies. Former Territorial [Old Capitol], "that lovely, calm, gold-domed antique building," watches the battles in the 
streets. Students occupy the office of tall, scholarly President Lawrence Esterhart and try to prevent a Dow Chemical interview. "Half the Value for Twice the Rent" is the landlords' first commandment according to the students who live on one block, and the description of their housing confirms every complaint.

5.

Boyle, T. C. THE WOMEN'S RESTAURANT. Penthouse 8, no. 9 (May 1977): 112-14, 128, 130, 132, 134. Also, as “A Women's Restaurant," in T. Coraghessan Boyle, Descent of Man, pp. 83-98. Boston: Little, Brown, 1979. 219 pp.

Grace and Rubie's on North Linn Street in Iowa City in the midseventies inspired a short story about a man determined to eat in their restaurant. "It is a women's restaurant. Men are not permitted. Women go there to be in the company of other women, to sit in the tasteful rooms beneath the ancient revolving fans and the cool green of spilling plants...."

6.

Bradbury, Malcolm. STEPPING WESTWARD. Boston: Houghton Mifflin, 1966. $390 \mathrm{pp}$.

The English university professor and novelist Malcolm Bradbury writes about an English novelist visiting an American university that in no way resembles Iowa. However, on the boat train and ocean liner to America, the fictional novelist meets a girls' college bagpipe band returning from a European tour. "It was a great success. They have had enormous audiences in Paris and Rome and Salzburg and Vienna and London. Europe is fascinated by American girls playing the bagpipes." Scotland also enjoyed the pretty girls with bare knees. (From 1952 onward for many years, Iowa's Scottish Highlanders toured Europe every four years.)

7.

Calderwood, Carmelita, and James Hearst. BONESETTER'S BRAWL. Ardmore, Pennsylvania: Dorrance, 1979. 144 pp.

Murder in the orthopedics department of a university hospital is the subject of a mystery by Carmelita Calderwood, once a nurse in The University of Iowa Hospitals and Clinics and coauthor of the textbook, Orthopedic Nursing. She was the first wife of James Hearst, distinguished Cedar Falls poet. After her death and Hearst's later remarriage, the second Mrs. Hearst found the manuscript of Carmelita's novel and it was completed for publication by Mr. Hearst. The time is August and September of 1941 and the place is a university campus with a few local names in recognizably altered form, such as the State River dividing the 
hospital from the Union and east campus. The Bonesetter's Brawl is the annual orthopedics dance.

8.

Casey, John. AN AMERICAN ROMANCE. New York: Atheneum, 1977.

$321 \mathrm{pp}$.

Theater and film on the fringes of The University of Iowa provide the setting for this novel of the 1970s. West Liberty, the Coralville Reservoir, and the all-girl bagpipe band are mentioned in passing.

9.

Cassill, R. V. AND IN MY HEART. Paris Review 33 (1965): 97-156.

A professor of English, said to be based on Edwin Ford Piper (1871-1939), who taught at lowa from 1905 until his death, is the hero. Like Professor Piper, the fictional professor is a poet from Nebraska, but he is a generation younger and the story is set in the 1950s. The physical setting is barely described but the unnamed school has a university hospital.

10.

Cassill, R. V. DORMITORY WOMEN. New York: Lion Books, 1954. $160 \mathrm{pp}$.

A panty raid at Blackhawk $U$ begins the action, which continues with several violent deaths. The Memorial Union footbridge connects the two sides of the campus and there are canoes full of students on the river. Two thousand students cheer at a pep rally and the football team loses to Notre Dame, 21-7.

11.

Cathey, Bill Robert. THE COWBOY ANGEL RIDES. Ph.D. dissertation, The University of Iowa, 1971. $160 \mathrm{l}$.

A fictional graduate student in English writes about his lower-class landlady and her family and many of their personal problems. The house is south on Capitol Street near the Rock Island trestle. The student photographs a sad affair of a wedding at the tall red brick St. Patrick's Catholic Church, huge and lofty. The father of the groom did not know the name of the bride. The university is not mentioned.

12.

Clothier, Peter. CHIAROSCURO. New York: St. Martin's Press, 1985. $259 \mathrm{pp}$.

Cynthia, a native of North Liberty, is a character in a mystery set in the art world of New York. "I had often reminded her that I had rescued her from the fate of completing a doctorate at the University of Iowa. 
"That was in 'sixty-four. I had a residency there--a healthy chunk of salary for half a year, a respectable two-day teaching schedule with graduate students only, and a cramped but workable studio in a quonset hut down by the river. The students were reputed to be the pick of the crop. You could have fooled me. Barely a handful of them could draw."

13.

Collins, Max Allan. A SHROUD FOR AQUARIUS. New York: Walker, 1985. 174 pp.

The author's hometown, Muscatine ("Port City"), and Iowa City are the principal locations of this contemporary mystery novel. Collins plays with the alternate spellings of Old Capitol Center ("a vaguely institutional look-a mall in a police state"), Plaza Centre One, and the Civic Center. The interior and exterior of Bushnell's Turtle are shown in detail. Near that restaurant, "A new Holiday Inn loomed at our right, cutting across the plaza at an angle, a tan, modern building with lots of windows and along the side a restaurant with pregnant greenhouse windows. Iowa City so desperately wanted to be California, in the midst of a cornfield." The most important business establishment in the mystery is Things \& Things \& Things, disguised as ETC., ETC., ETC.

14.

Corey, Paul. COUNTY SEAT. Indianapolis: Bobbs-Merrill, 1941. 418 pp.

Paul Corey's Mantz trilogy of Iowa farm novels sends the youngest son of the Mantz family off to The University of Iowa in 1923 at the end of The Road Returns and follows him through to graduation in 1927 in County Seat. The student, Otto, appears mostly through letters and visits home to western Iowa. He works his way through school slinging hash, fixing phonographs, and working in a departmental library. His widowed mother proudly takes the train to Iowa City for commencement. "The huge concrete bridges across the Iowa River fascinated her; she liked to stand by the heavy railings and watch students canoeing."

15.

Exley, Frederick. PAGES FROM A COLD ISLAND. New York: Random House, 1975. 274 pp.

The author's reaction to the death of Edmund Wilson is the principal theme of this fictionalized autobiography, the second volume of a projected trilogy. The settings are Upstate New York, Florida, and Iowa City. Exley taught briefly at the Writers' Workshop, and the Iowa City locations in the book are his room at the Iowa House, the EnglishPhilosophy Building, and downtown bars including Donnelly's. In one of 


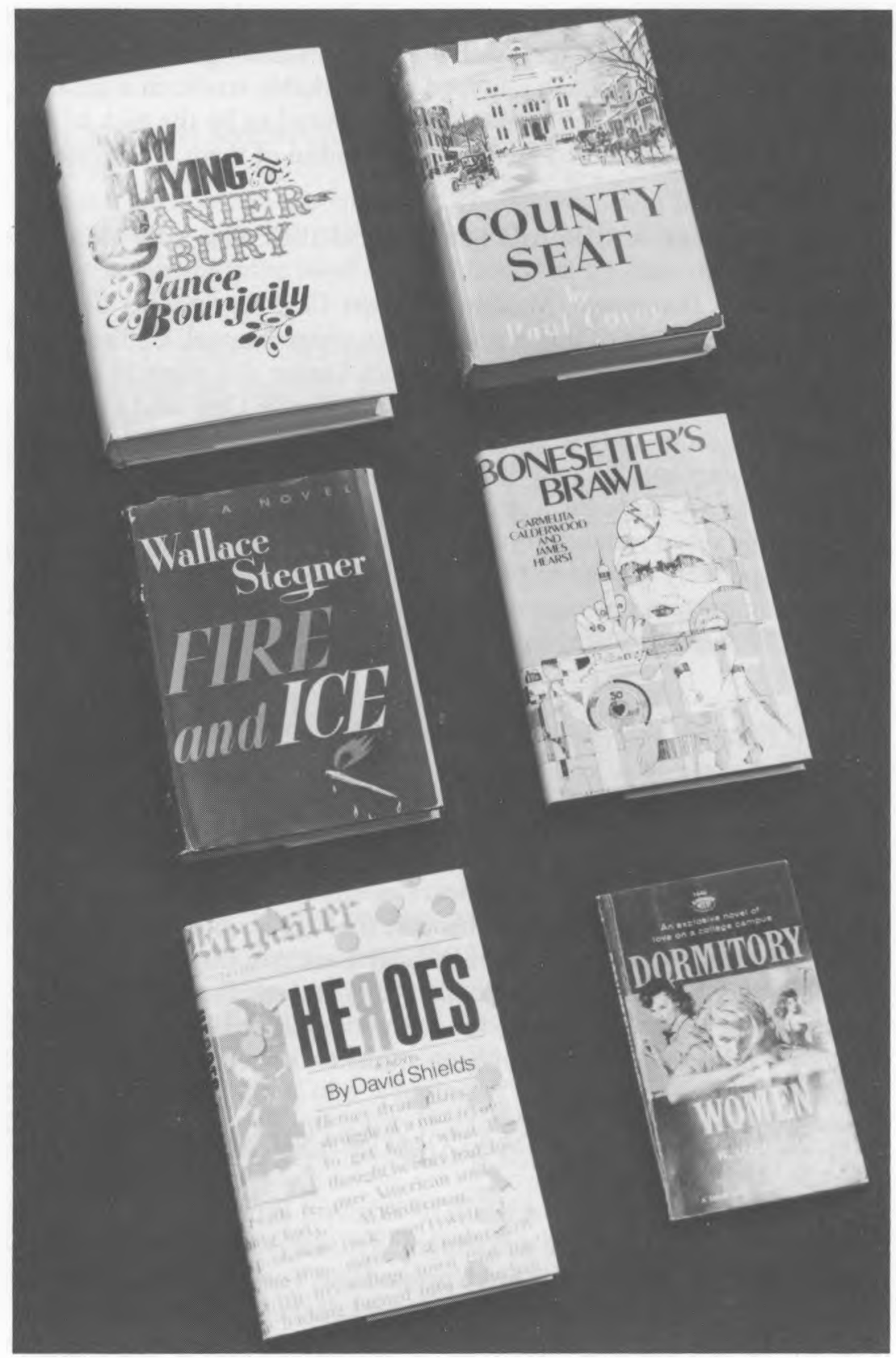

Six novels in which an Iowa City background is discernible. From copies in The University of Iowa Libraries. 
the bars he meets the Epstein brothers, who operated a bookstore in Iowa City in the 1970s.

16.

Glasser, William Arnold. NETHER MIND. Ph.D. dissertation, The University of lowa, 1965. 2121.

Nine pages of this creative dissertation are at "any Midwestern university," where the narrator and his wife rent an apartment on the hill above the river, with views of the Gothic-towered hospital and the corrugated-metal shacks that are the school's married-student housing. Thousands of roosting blackbirds annoy the people of the town.

17.

Hardwick, Elizabeth. THE SIMPLE TRUTH. New York: Harcourt, Brace, 1955. 223 pp.

In late 1949 a fraternity member in Iowa City was accused of killing his sorority girlfriend. The 1950 murder trial was sensationally reported by big-city newspapers. In this novel based on that trial, a married graduate student and a faculty wife attend the trial together and discuss courtroom activity and life in the Iowa town that is the home of the State University. The student and his own wife were squeezed into a one-room apartment. "Although only of moderate size this single room had so many recesses given over to some function of housekeeping usually placed alone that there was hardly anything, unless it might be the little spot in the center covered with a tiny, red tufted rug, that could properly be called the living room itself."

Most of the transients in this university town "simply abhorred the place with a manic volubility. The aliens who had settled for good had more troubled minds, recalling sometimes with a sigh the lost hills and bays of San Francisco, horseback riding in Arizona, and most of all the great East from the Green at Concord to the steak and fish houses of Baltimore.... Here also at the University were many teachers from Europe ... remarkable souls pacing the Iowa pavements. . . . They were in America, no doubt about that, even if perhaps they had not bargained for so completely the real thing and wondered at their fate."

18.

Harter, Evelyn. DR. KATHERINE BELL. Garden City, New York: Doubleday, 1950. 274 pp.

Katherine Bell is a woman doctor from Iowa in a novel by a physician's daughter who became a book designer. The early pages cover Katherine's student years in the early 1920s at Sioux University on "Lake Sioux, where the university buildings and the business part of Prairie City lay stretched and intermingled along the southern tip of the lake." Some of 
the action takes place in the women medical students' rooming house and in a popular restaurant. "Sobi's Restaurant was directly across from the Arts campus, and a block from the medical college, a group of old brick buildings weakly Gothic in architecture. The restaurant stood at the junction of two main highways and drew its clientele from students, truck drivers, and townspeople."

19.

Irving, John. THE WATER-METHOD MAN. New York: Random House, 1972. $365 \mathrm{pp}$.

This early John Irving novel is about a Ph.D. candidate in comparative literature at The University of Iowa who lives at 918 Iowa Avenue and sells football pennants. The wounded hero, carrying a dead duck, looks "across the river, on the bank that looks like an Army barracks-stacked with the war-built Quonset huts, now called Married Student Housing. ..."

20.

Irving, John. THE WORLD ACCORDING TO GARP. New York:

Dutton, 1978. 437 pp.

T. S. Garp, an Eastern novelist, in the first chapter of his The World According to Bensenhaver (in reality a chapter of John Irving's novel), writes about a visiting professor looking out of his office window in what might be the English-Philosophy Building in a university town near a smaller town named Hills. Garp's father-in-law "had been a two-time Big Ten wrestling champion at the University of Iowa." The motion picture version of The World According to Garp omitted the Iowa City connection.

21.

Jeffery, Ransom, and John Keeble. MINE. New York: Grossman, 1974. $280 \mathrm{pp}$.

Hills, Oasis, and Iowa City are all settings for Mine. Sand Road, the bus terminal in "the back room of a semidefunct hotel" [the Burkley Hotel, now demolished], football Saturdays, and a demonstration at the Student Union are in the background. A minor character is upset because urban renewal will take away Irene's bar. "Put the little man out of business. They haven't got the right. Over twenty years this place has been an institution. By God, Tennessee Williams drank beer here. . . Phil Roth was a customer too. Flannery O'Cennor. Bill Williams. Nelson Algren. Richard Hugo. Jim Whitehead. See those pictures on the wall? ... Ferlinghetti and Ginsberg come by whenever they're in town. Saul Bellow, too." 
22.

Kinsella, W. P. THE IOWA BASEBALL CONFEDERACY. Boston: Houghton Mifflin, forthcoming.

This novel, like Kinsella's Shoeless Joe, will be set in Iowa City. Pearson's Drug Store is praised again. "Tall chocolate malts, thick as cement, served in perspiring glasses." The Airliner, Bushnell's Turtle, and Donnelly's also appear. Several excerpts have already been (or are about to be) published: in Descant (Toronto) (Fall 1983), Arete: The Journal of Sport Literature (Spring 1985), and Sports Illustrated (forthcoming baseball issue, probably in April 1986). Some of these also appeared in Kinsella's The Thrill of the Grass (1984) and in Here's the Story: Fiction with Heart, edited by Morty Sklar (1985).

23.

Kinsella, W. P. SHOELESS JOE. Boston: Houghton Mifflin, 1982. $265 \mathrm{pp}$.

A Canadian student at the Iowa Writers' Workshop, W. P. Kinsella wrote a novel combining J. D. Salinger, baseball, and corporate farming. The title comes from Shoeless Joe Jackson of the Black Sox of 1919. Kinsella's hero, Ray Kinsella, "came to lowa to study, one of the thousands of faceless students who pass through large universities, but [he] fell in love with the state." His depiction of a real Iowa City mentions Old Capitol, West High School, Iowa City glass, the Iowa Theater, Donnelly's Bar, and the public and University libraries. The author was mistakenly led to believe that lowa City, not Mason City, was Meredith Willson's River City in The Music Man. "Shady streets, very old white frame houses, porch swings, lilacs, one-pump gas stations, and good neighbors. ... We have a drugstore with a soda fountain. ... It's dark and cool and you can smell malt in the air like a musky perfume. And they have cold lemon-Cokes in sweating glasses, a lime drink called a Green River, and just the best chocolate malts in America. It's called Pearson's-right out of a Norman Rockwell painting."

24.

Lafore, Laurence D. NINE SEVEN JULIET. Garden City, New York: Doubleday, 1969. 300 pp.

A retired professor of literature at the state university, once a pilot and now living on a farm at the age of 80 , is the hero of a mystery by Lafore, late professor of history at The University of Iowa. "The city of Buchanan and Van Buren County bear some general resemblance to Iowa City and the beautiful country around it but the details ... are imaginary," according to the author's introduction. The title is part of the serial 
number both of the light plane owned by Lafore and of a similar airplane in the novel.

25.

Leggett, John W. MAKING BELIEVE. Boston: Houghton Mifflin, forthcoming.

A clergyman whose career parallels that of controversial Bishop James A. Pike (1913-69) serves as rector of green clapboard Trinity Episcopal Church in a section of this novel by the director of the Iowa Writers' Workshop. The clergyman is at the center of the student antiwar demonstrations in "Iowa City, a turn-of-the-century town whose Victorian rooming houses and maple-shaded walks still held out against the bulldozers and transit-mix concrete trucks. A gold-domed Old Capitol building presided over a University which sprawled along both banks of the Iowa River. On its steps a hoarse speaker was haranguing a circle of thirty students.

"Facing it the town appeared to be under siege. In a doorway a merchant swept shattered glass into a dustpan. Many show windows had been replaced by widths of plywood. The few which had been spared were protected by embrasures of chickenwire. ... There was a smell of destruction in the air."

26.

McMenamin, Thomas John. CALL ME MANNESCHEWITZ. New York: Scribner, 1971. 239 pp.

An M.F.A. candidate in pottery in Iowa City is the hero, though the novel has very little on either the town or the University.

27.

McMillen, Howard. THE MANY MANSIONS OF SAM PEEPLES. New York: Viking Press, 1971. 299 pp.

Samuel T. Peeples is a landlord in the college town of Kanecka City, Kansas. "The group of four buildings Peeples called the White House, the Brownstone, the Cottage, and the Chicken Coop were referred to sarcastically by the residents of Kanecka City as Peeples' Paradise. Peeples had adopted the name as his own creation...." The property bears strong resemblances to Black's Gaslight Village in Iowa City. Many of the townspeople have Czech names.

28.

McMurtry, Larry. MOVING ON. New York: Simon and Schuster, 1970. $794 \mathrm{pp}$.

Texas novelist McMurtry sends a couple from Rice University northward in Moving On. "Flap had worked hard on his dissertation and had 
two chapters done and only three to go, and he had secured a job, a better one than he had expected, at the University of Iowa, in Iowa City. Emma was gloomy for a few days at the thought of Iowa, but then someone told her that there was a big writing center there, with hundreds of lively writers in it. The news cheered her a bit. She sat around for several days reading Letting Go and imagined herself slimmed up and having an affair with a young writer of some kind." The characters from Moving On reappear in other McMurtry novels, and in his Terms of Endearment, recently made into an award-winning motion picture, Flap teaches at colleges in Des Moines, lowa, and Kearney, Nebraska.

29.

Murphy, Robert W. A CERTAIN ISLAND. New York: M. Evans, 1967. $239 \mathrm{pp}$.

The Laysan Island cyclorama, in The University of Iowa Museum of Natural History, Macbride Hall, is the result of a collecting expedition by the museum in 1911. This juvenile novel is about a follow-up expedition to Laysan, now part of the Hawaiian Islands National Wildlife Refuge. The hero, a freshman at the University in a little college town on the Iowa River, "bears some outward resemblance to Alfred M. Bailey ... the Director of the Denver Museum of Natural History." Bailey (1894-1978), an Iowa City native, was a member of such an expedition, 1912-13. The hero's mother buys her furniture at the Amana Colonies. The author repeats the discredited theory that the Mound Builders were not Indians.

30 .

Nelson, Peter N. COOLEY AND KEDNEY. Iowa Review 14, no. 1 (Winter 1984): 73-102.

The Black Angel in an Iowa City cemetery, the University Hospitals' sperm bank and the poet-activist David Sundance appear in the story of a fictional poet and her enduring love for an art department photographer killed in a plane crash near Cedar Rapids. She moves around the country but returns to Dubuque for happy memories and to Iowa City "to teach at the same Writers' Workshop she'd graduated from...."

31.

Newborn, Sasha. THE BASEMENT. Santa Barbara, California: Mudborn Press, 1978. 179 pp.

The Basement interweaves experiences as a teacher in Africa with life in a basement apartment on lowa Avenue, Iowa City, in half a block of houses torn down by the city for more parking space, leaving the Unitarian Church on the corner. The narrator sees a "chair broken by Vonnegut or Roth"- and Bourjaily once spoke to him! 


\section{2.}

Rhodes, David. ROCK ISLAND LINE. New York: Harper \& Row, 1975. 379 pp.

Sharon Center, Iowa, and Philadelphia, Pennsylvania, are the settings, but the Iowa City railway station is the scene of key transitions in the life of a small boy growing to young manhood. His description of Iowa City is concise. "Not big. There's a university there. That's nearly as big as the whole town."

33.

Roth, Philip. LETTING GO. New York: Random House, 1962. 630 pp.

Letting Go opens at The University of Iowa in the fall of 1953. The hero and his friends are graduate students, living in apartments and in married students' barracks. Coe College, where one student also teaches, and Dubuque Street are named, but Roth concentrates on the lives of his characters rather than on the setting.

34.

Sandroff, Ronni. PARTY PARTY: GIRLFRIENDS: TWO SHORT NOVELS. New York: Knopf, 1975. 196 pp.

Both novelettes are set in Candle City, Iowa, which has the Mainliner bar and College and Market streets. One can walk "down past the hospital complex, under the campus elms, past the girls' dormitories into the suppertime emptiness of the downtown area." Among minor characters in Party Party, "Kenny Loren owns a bookstore in town and prints the local Socialist sheet in his cellar. He's forty years old." Some readers may be reminded of the now-defunct Paper Place bookstore.

35.

Shattuck, Katharine. THE NARROWEST CIRCLE. New York: McDowell, Obolensky, 1958. 279 pp.

A professor and his wife and daughter and their guest, a young woman who has completed her student years, spend a summer in the country at a stone mansion above Rockville, Kansas, a quarrying ghost town. The setting strongly resembles Paul Engle's former summer house at Stone City, Iowa, "the stone church with its square tower ... the single winding road on which the town was strung ... most of all the mansion house on the hill." At the end of the summer the group returns to an unnamed university town with a hospital hill. Robert Frost was at a party in the town a few nights before the novel began. 
36.

Shields, David. HEROES. New York: Simon and Schuster, 1984. $347 \mathrm{pp}$.

To date, the only UI basketball novel is Heroes. A sportswriter for the River City Register investigates a recruiting scandal involving the River State University Stallions, an Oxford, Iowa, philanthropist who "gets hospital wings named after him," and the reporter's own wife, who hopes to get tenure in English. The reporter, his wife, and their seven-year-old diabetic son are unusually appealing fictional characters in their reactions and weaknesses. The novelist condemns the Downtown Refurbishment Project, which gutted the best bar in Johnston [sic] County. "The pedestrian greenway and Sycamore Mall and Plaza Center [sic] One have ruined this town, and now the Old Capitol Center promises to bury it under eight feet of cement." His newspaper's wackiest columnist, Susie Smyth, "takes her show-stopping vampstripper parody to motel lounges and bars around town." River City has the River State Clinics, KHAK and KRNA, the downtown Rec Center, the Coralville Strip (studied by a university class), and the Coralville Reservoir.

37.

Spivak, Talbot. THE BRIDE WORE THE TRADITIONAL GOLD. New York: Knopf, 1972. 196 pp.

The bride teaches Sanskrit poetry to Iowa undergraduates while her husband commutes to teach drugstore Latin at a liberal arts college sixty miles south of their Johnson County farmhouse.

38.

Stegner, Wallace. BEYOND THE GLASS MOUNTAIN. Harper's Magazine 194 (May 1947):446-52. Also in his The Women on the Wall, pp. 1-14. Boston: Houghton Mifflin, 1950. 277 pp.

Two alumni, an Iowa City businessman and a Yale professor, meet after 17 years apart. The visitor from Yale "found himself at the corner of College and Dubuque Streets in Iowa City, at a little past ten on a Sunday morning in May, and as he stopped on the corner to let a car pass, the utter and passionate familiarity of everything smote him like a wind. ... the stone lace of the hospital tower ... the union and the reserve library [Old Armory] strung out along the riverbank. ..." He climbed the hill to the field house. "He would have liked to go in under the big round roof just to soak himself in the sensations he remembered: smell of lockers opened on stale gym clothes and stiff sweated socks; steam and 
thumping radiators and liquid soap smell; sweat and medicated foot baths and the chlorine smell and the jiggly reflecting chemical blue of the pool ...."

39.

Stegner, Wallace. FIRE AND ICE. New York: Duell, Sloan and Pearce, 1941. $214 \mathrm{pp}$.

Stegner, who earned his M.A. and Ph.D. degrees at Iowa and who became a distinguished novelist and teacher of writing at Stanford University, wrote Fire and Ice about a desperately poor freshman active in the Young Communist League while holding down several student jobs at once. There is little physical description of the campus and town but Stegner finely portrays the mind of his fictional student and the reactions of the other characters.

40.

Stegner, Wallace. THE VIEW FROM THE BALCONY. Mademoiselle 27, no. 3 (July 1948): 68-70, 103-9. Also in his The Women on the Wall, pp. 93-120. Boston: Houghton Mifflin, 1950. 277 pp.

An English war bride is among a group of married graduate students, all veterans, and their wives living in a fraternity house for the summer. Their Graduate School is in Indiana but across the highway and the Wawasee River beyond is a city park with lions roaring in the zoo.

41.

Sunwall, James Raymond. MARCHING AS TO WAR. Ph.D. dissertation, The University of Iowa, 1962. 313 l.

A veteran becomes an aide at the new (in 1951) Veterans' Administration hospital on the hill above the sickle-shaped drive in Center City. The aide had been a student at the University, taking classes on the other side of the Iowa River. On July 4 he watches the fireworks in Riverside Park, near the zoo.

42.

Twito, Tom. EXCERPTS FROM THE AUTOBIOGRAPHY OF CONSTANCE TURABIAN. Vital Signs (April 1982): 1, 6.

A short story in the medical students' newsletter is a parody set against the background of the fictional University of Iowa Sportswriter's Workshop. Characters include not only writers but such sports artists as Lasansky, designer of football programs, and Frank Miller. Conversationalists include F. J. Hastings, who "was always agreeing in those days," Roy Carver, sports fan James Van Allen, and Meredith Willson. 
43.

Wakefield, Dan. HOME FREE. New York: Delacorte Press, 1977. $245 \mathrm{pp}$.

The ex-student hero spends the fall of 1970 in lowa City as part of a year-long journey that begins in Urbana, Illinois, and ends in Los Angeles with long stopovers in Boston and in Maine. The author has a good eye for local detail. Donnelly's Bar, soon to be lost to urban renewal, appears along with the Airliner. "There were old-fashioned hardware and dime stores with wooden floors, bars with billiard tables, diners that served homemade chili, the Epstein Brothers' homey bookstores where you could browse all day without being hassled."

44.

Wallis, Ruth Sawtell. COLD BED IN THE CLAY. New York: Dodd, Mead, 1947. 212 pp.

The author, who was an anthropologist at the Iowa Child Welfare Research Station, 1929-31, at the beginning of her college teaching career, combines elements of more than one college town in this academic mystery set near the end of World War II. "A State University was holding its annual commencement... . Flat in the middle of the U.S.A., a college campus ought to meet a cornfield. Corn paid taxes and taxes paid for the pomp and circumstance which the student band was demanding for the boys and girls. . . . In June, 1945, less than one in ten of these graduating seniors was male." Among the graduate degrees is a Master of Child Welfare.

45.

Welt, Elly. IOANNA REDDINGHOOD. New York: Random House, 1980. $314 \mathrm{pp}$.

A publishing party with a flock of English professors and the staff of the Writers' Workshop is a highlight of a medical murder mystery featuring a Spanish anesthesiologist at the University Hospital, University City, who owns three farms and subscribes to Wallaces Farmer.

46.

Weverka, Robert. THE STORY OF BILL. New York: Bantam Books, 1983. 184 pp.

Bill Sackter (1913-83) operated the coffee shop in The University of Iowa School of Social Work after his release from mistaken institutionalization in Minnesota for 44 years. Bill became one of Iowa City's most beloved and celebrated citizens. His life was the subject of two television docudramas. This novel, based on the television scripts, outraged Bill's friends. The author never interviewed anyone who knew Bill and the 
novel adds nothing about Bill's life not covered in the scripts. The reader will learn little about Iowa City.

47.

Wirt, Mildred A. GHOST GABLES. Cleveland: World Publishing Company, 1939. $205 \mathrm{pp}$.

Ghost Gables begins at the boat landing on "the winding Big Bear river which flowed through the town, dividing the campus of Ardmore college." The tomboy heroine of this mystery story for girls rents canoes to students for her father. She helps a new friend, a freshman, turn a mysterious old house into a rooming house for other women students. There is a "second-hand book store on Clinton street" in Ardmore. 